\title{
Women and Border Policing at the Edges of Europe
}

\begin{abstract}
While states around the world have responded to mass mobility by increasing border policing, our knowledge of the daily reality of that form of policing remains limited. How migrant women are policed has been particularly neglected. The political and practical difficulty of examining the context, process and experience of border control practices appears often to be insurmountable. This article contributes to filling some of the gaps in our knowledge by drawing on ethnographic data collected over a twelve-month period in Greek immigration detention centres from 2011 - 2012. In it we examine the experience of policing and irregular entry across the Greek Turkey border - an entry-point to Europe that is routinely regarded as being in crisis. As we will demonstrate, border policing at this site is capricious and unpredictable. It is also highly racialized and gendered.
\end{abstract}

Keywords: Border policing; women migrants; Greece; race and gender; immigration detention; intersectionality

\section{Introduction}

As states around the world have responded to growing numbers of people on the move by tightening their borders, strategies of border policing have assumed significant policy and political weight (Author, 2004; Angel-Ajani, 2003; Green \& Grewcock, 2002). Through the securitisation of land and maritime borders, governments have sought to deter and disrupt the unauthorised mobility of people, often at the expense of their human rights. In so doing, they have reshaped policing, borders and sovereignty and the ways groups are included and excluded at national borders (Goldsmith \& Sheptycki, 2007; Weber, 2006; Author 2006; Angel-Ajani, 2003; Melossi, 2003).

Women and children now make up sixty per cent of people on the move in Europe. However, we know little about the nature and ramifications of their experiences of crossing borders (although see Gerard, 2014). What little we do know is troubling with researchers finding that practices of border securitisation have created a more hostile and violent environment for women, leading to higher incidence of rape and sexual violence in militarised border zones 
(Pickering, 2011; Carpenter, 2006). Though scholars have speculated that women are less willing to play 'cat and mouse' with border policing agents or to make repeated attempts at crossing highly securitized borders (Richter and Taylor, 2007), women, particularly those who are seeking asylum, remain vulnerable (McKay, 2003; Crawley, 1999).

In a relatively short period, borders and the control of irregular mobility have moved from a peripheral to a more pressing concern for criminologists in Europe, North America and Australia (see, inter alia, Aas, 2011; 2013, Andreas, 2003; Author, 2008; Bosworth and Guild, 2008; Author 2014; Fassin, 2011; Gerard and Pickering, 2012; Grewcock, 2011, Pickering and Weber 2006; Weber and Pickering, 2011, Weber, 2006). However, we are still building an empirical base from which to understand the micro politics of irregular migration and border control practices. On the one hand, official governmental discourse presents geographical divisions as fixed and defensible. On the other hand, a growing body of interdisciplinary academic research has comprehensively disrupted such accounts, redirecting attention to those who move across borders and the ways they experience border policing, as well as to the perspective of the security forces and their own conceptualization of border control (see for example Aas, 2005; Author, 2005; Pickering \& Weber, 2013; Salter, 2007; Weber \& Bowling, 2004; Wilson \& Weber, 2002; Wonders, 2007; Sanchez, 2016). Empirical work in the US and Europe has been instrumental to this discussion (Bigo and Guild, 2005; Vaughan-Williams, 2012; Williams, 2015; Pallister-Wilkins, 2015), highlighting the multifaceted and diverse nature of border control.

In this paper, we contribute to the scant body of research in this field by offering an analysis of accounts drawn from a range of migrant and asylum seeking women and border police in Greece in the central holding facility for migrants in Athens and the Athens airport detention centre. Interviews were conducted over a twelve-month period in 2011-2012 by one of the 
authors in the first site as a research officer and in the second when she was working for a Greek NGO. ${ }^{1}$ While the Ministry of Interior and Public Protection had overall responsibility for immigration issues and detention facilities, the Hellenic Police were the approving body for undertaking this research. In negotiation with the relevant authorities, we were given full access to interview staff and detainees and permission to move freely throughout the centres. Detainees were recruited through the social service, and in consultation with detention officers. Staff respondents were chosen based on their experience of having worked both at the border and in detention facilities ${ }^{2}$.

Below, we set their testimonies against the political and social context of Greece and the European Union (EU). By focusing on the micro politics of producing, performing and crossing borders we highlight the incoherence and contradictions between prevailing logics of border control that are fundamentally gendered and racialized. This research is part of a larger collaborative program of work building an empirical base of border criminology (see for example, Author, 2014; Bosworth and Aas, 2013; Pickering and Ham, 2013; Weber, 2013; Author, 2014).

\section{Greece in Fortress Europe}

The external frontier of the European Union (EU) between Turkey and Greece is made up of a $203 \mathrm{~km}$ land border in the Evros region in the North and a sea border on the Aegean in the South. Characterised by multiple, alternative points of crossing, as well as by sustained flows of people who have resisted the intensification of border control policies, the Greek-Turkish border has, since 2009 , been dramatically affected by the regional tumult caused by forced

\footnotetext{
${ }^{1}$ At the time of the research, the central holding facility for migrants in Athens was the only centre that held men, women and children in the city and was the main detention site that people from the border were transferred to. Most detention officers employed there had been seconded to the Evros border police as border officers. No independent academic research in it had previously been permitted.

${ }^{2}$ Border officers are regular police officers on rotation of maximum three months because it is very difficult to find people who are locally established at border locations or who would be willing to relocate there for a longer stretches of time.
} 
displaced people trying to find safety or a better life in Europe. In 2015, for instance, for which we have the most complete statistics, it was estimated that more than 850,000 people crossed from Turkey into Greece by land and sea. Sea arrivals, specifically, increased that year by an astonishing 1,075.3 per cent, earning the label from the UNHCR of a 'maritime refugee crisis'. More than 85 per cent of those arriving in Greece were from countries experiencing war and conflict, principally Syria, Afghanistan, Iraq and Somalia. Women and children accounted for more than 60 per cent.

In late January 2016, the EU gave Greece a three-month ultimatum to prevent arrivals from Turkey. Failure, it warned, would vacate Greece's membership of the borderless Schengen area. Austria and several Balkan countries began building rows of fences and FYROM (Former Yugoslav Republic of Macedonia), in March 2016, sealed its southern border with Greece. In response, Greece expanded its detention and reception capacity. At the time of writing, there are more than 50 emergency reception sites and five hotspots, as well as a number of informal sites $^{3}$, operating with capacity for around 60,000 people. In addition to these new facilities, Greece continues to use a number of pre-removal detention centres, older dedicated detention sites, and numerous border guard and police stations.

Detention has been a core aspect of border policing in the country for a number of years, as subsequent governments have sought to make Greece an unfriendly destination for migrants and secure its borders. ${ }^{4}$ The emergent policies, enacted under conditions of severe economic privation, seek to deter migrants through fencing and gatekeeping (Triantafyllidou and

\footnotetext{
${ }^{3}$ http://rrse-smi.maps.arcgis.com/apps/MapSeries/index.html?appid=d5f377f7f6f2418b8ebadaae638df2e1

${ }_{4}^{4}$ Integrated Program for Border Management and Combating Illegal Immigration presented on 07.09.11 to the Cabinet by the former Minister of Citizen Protection, Christos Papoutsis. See, http://www.minocp.gov.gr/index.php?option=ozo content\&lang=\&perform=view\&id=3790\&ltemid=513
} 
Ambrosini, 2011), and by making detention facilities unlivable. The government also operates a formal deportation system.

The investment in safeguarding Greece's porous borders was completed by the 2012 erection of a $10.5 \mathrm{~km}$ fence along the most transited part of its land border with Turkey. That same year saw the deployment of 2,000 additional border guards along the Evros river under Operation Aspida, making the Greek-Turkish border the 'centre of gravity' of Frontex's operations $^{5}$. These measures proved effective in discouraging immigrants or smugglers from this particular route. They did not stem the flow of arrivals however. Instead, migrants were forced on far more dangerous sea-crossings to the Greek islands, with a resultant increased death toll in the Aegean (Pallister-Wilkins, 2015).

Resourceful Hellenic police and coastguard have employed, over the years, a number of other, more informal techniques to control the borders with Turkey, creating a chain of transnational exploitation. Though it is not easy to document these cases and the scale with which they occur, testimonies collected by human rights organizations and NGOs concerning illegal deportations and push-backs suggest that these practices have been routine, systematic, brutal and, above all, long-standing (ProAsyl, 2007; HRW, 2008; NOAS, Aitima and NHC, 2009). In 2013, for example, Amnesty International (2013) reported that coastguard officials were puncturing inflatable boats or otherwise disabling them before setting them adrift towards the Turkish coast. Five years before, Human Rights Watch had alleged Greek

\footnotetext{
${ }^{5}$ The policing of external borders has often been referred to as high policing - being driven by national security and international relations concerns (see Andreas, 2000) and has been set against so called 'low policing' routinely regarded as the bread and butter policing we know and love in criminology. However, the Hellenic policing of the Greece Turkey border does not neatly conform to this classification. Primarily because there is not a border policing apparatus clearly distinct from the civilian police - but rather they are largely one and the same. The same police are involved with the detection, interception, arrest and processing of irregular migrants at the physical border, their summary return to Turkey or entry into the asylum system, the arrest and round up of undocumented non-citizens, the operation of detention centres, and deportation processes. The policing of irregular migrants is very much seen as part of the ordinary criminal policing continuum.
} 
officials simply deposited migrants at the Turkish borders, outside the readmission agreement signed by the two countries in 2001, which has never been fully implemented (Human Rights Watch 2008).

In addition to hardening its external border, Greece has sought to make conditions inside detention centres act as a form of deterrence. As the Head of Hellenic Police advised his officers, 'we have to make their lives miserable, otherwise they will be under the impression that coming to Greece they will be free to do what they want ${ }^{6}$. Faced with the prospect of prolonged stay inside a Greek detention centre under deplorable conditions, this officer hoped that irregular migrants would not make the perilous journey to Greece.

In response to the 'persistent lack of action of action to improve the situation', the Council of European Committee for the Prevention of Torture and Inhuman and Degrading Treatment or Punishment took the 'exceptional' measure of making a "Public Statement Concerning Greece" in relation to Article 10 of the European Convention on Torture and Inhuman and Degrading Treatment or Punishment ${ }^{7}$ : Despite significant numbers of irregular migrants entering Greece via its eastern land and sea borders over a period of years,' it observed, 'no steps were taken to put in place a coordinated and acceptable approach as regards their detention and treatment.' (para 3 of the statement). This is not the first time that Greece has been publically castigated for the conditions of its detention facilities. Numerous NGO reports cite overcrowding, poor conditions, and lack of access to assistance, including legal, social and medical support (HRW, 2013; Amnesty International, 2013).

\footnotetext{
${ }^{6}$ http://news247.gr/eidiseis/koinonia/arxhgos-el-as-gia-metanastes-na-toys-kanoyme-to-vio-aviwto.2561326.html ${ }^{7}$ The CPT has resorted to this action only another 5 times in the past; in 1992 and 1996 to Turkey and to Russia in 2001, 2003 and 2007 for the situation in Chechnya.
} 
Police aim to arrest and detain all new arrivals, including those who claim asylum, victims of torture and human trafficking, disabled persons, pregnant women, and minors (see Author, 2013). Thus, in 2013, as part of a massive national policing operation known as Xenios Zeus ${ }^{8}$, the Ministry of Interior authorized daily police 'sweep operations' to arrest and detain all irregular migrants in Greek territory. As former Minister of Citizen's Protection, Nikos Dendias put it: 'Our aim is that every illegal migrant, unless the competent authorities decide that he is entitled to international protection, will be detained until he is returned to his home country ${ }^{9}$,

Following their arrest, everyone was issued with an automatic deportation order without a hearing or any consideration of protection obligations. Such deportation orders were and remain rarely enforced, however, because most irregular migrants lack the travel documents not only to enter but also to leave the country legally. Thus, only one quarter $(24.5 \%)$ of the 491,411 orders to leave issued by the Greek authorities between 2008 and 2013, were enforced. Consequently, the number of arrestees soon exceeded the number of detention places available. In response, the government engaged in a large-scale investment in preremoval detention establishments to increase the return rate.

Despite all this policy activity and investment in tough policing measures, the current refugee influx serves as a stark reminder that the 'erection of metaphorical and actual walls and the desire to stop irregular migration do not seem capable of repressing migration movements' (Tsianos and Karakayali, 2010). The Greek state has managed neither to curb arrivals nor remove the majority of those subject to deportation orders. Instead, detention has been

\footnotetext{
${ }^{8}$ Named with savage irony, in reference, to the ancient Greek God Zeus to symbolise hospitality to and patronage of foreigners (Human Rights Watch, 2013).

9 http://www.yptp.gr/index.php?option=ozo content\&lang=GR\&perform=view\&id=4736\&ltemid=579
} 
employed capriciously, shaped by traditional racialized and gendered ideologies. What, under these circumstances are we to make of these practices? What explains the harsh response to the arrival of vulnerable people? These questions animate the next sections. In them, as we will demonstrate, women offer a complex range of reasons for and accounts of their migration, while staff fall back on familiar racialized and gendered tropes. Together their testimonies illuminate the intersectional nature of migration and its control.

\section{Why women migrate}

"You are obliged to work for your kids. We all do it for the kids. I talk to them and I realize I miss moments of their lives. I send them shoes and one day it was size 39 and now it is 41. You miss a lot" (Fieldnotes, February 2012; Georgian woman to an officer)

All the women in this project explained their irregular entry into Greece as the result of a combination of factors. Common issues that lay behind their migration and the form it took included the lack of options they encountered for a long term regular entry for the purpose of work, unrealistic requirements of family reunification processes, and the development and availability of smuggling networks. These factors occurred against a backdrop of the Greek asylum system that, at the time of research, had an acceptance rate of $1 \%$ and was still processing applications submitted in $2006^{10}$. Few of those who entered clandestinely wished to remain in Greece. Like more recent arrivals today, most hoped to travel north towards family, friends, and greater job opportunities. France, Germany, the UK and Scandinavia were their desired destinations. Greece was, for them, a transit country.

\footnotetext{
${ }^{10}$ The newly established Asylum Service, which is the first Independent Authority dealing with asylum claims in Greece as provided for in P.D. 113/2013 and has Regional Offices inside and outside of Attica, began operating on $7^{\text {th }}$ June 2013. The new Asylum Service is responsible for all new asylum applications and it was expected to fasten the asylum procedure and reduce the already existing backlog in the old system run by the Police. In 2015, there were still 23,324 applications pending from the old system. However, the acceptance rate has been risen up to $30,7 \%$ (for more on this http://www.asylumineurope.org/reports/country/greece)
} 
Participants came from Nigeria, Dominican Republic, Georgia, Eritrea, Somalia, Iraq, and Cape Verde. Two thirds had dependent children, all of whom had remained in their country of origin. The average respondent's age was 30 years old. Some had been in Greece for as long as three years while others had been arrested upon arrival a few days earlier. All had travelled as part of a group across the border even as other parts of the journey were undertaken alone.

In explaining the cause of their irregular entry into Europe, the women's accounts varied by nationality. Those from Eritrea, Somalia, Cape Verde and Iraq described circumstances relating to war and political persecution, while Georgians sought economic opportunities. Nigerians and women from the Dominican Republic described both political and complex social problems as motivating factors.

Wherever they were from, all the women we interviewed mentioned gender violence and domestic responsibilities as factors that contributed to their decision to leave their place of birth. Those who had fled political violence had been threatened with or had experienced sexual violence before or after their departure. Most women from Africa and Iraq talked about the deaths of male family members; without a male head of household, they described significant economic responsibilities in supporting their family especially their dependent children. In line with other research, all were in search of work (see, for example, Sassen, 1999).

Women from Somalia and Eritrea had moved due to the ongoing conflict in their countries of origin. However, they too, had concerns related to their economic survival. Sarah explained:

"I wanted to leave because the government is a problem and my husband is a soldier and I faced too many problems because of that and there is no job for me. For all this I wanted to go out. And from Eritrea I walked to Sudan.” (Sarah) 
Threats or experience of sexual violence compounded women's experience of conflict, as did their experiences of exploitation. Often, quite basic choices in life around relationships and living conditions had been seriously compromised. For example, Fola had left Nigeria because, as a woman, she was denied inheritance and was in danger of being married against her will:

"I don't have a mother, I don't have a father. I have a cousin and this cousin is treating us bad. All my father's property he collected from us. Many things like that. Before we see food he eats it. So I decided maybe to go find work and live. I don't have mother or father to say to me go or no go. Even my uncle don't know when I left. He wants me to marry one old man, one old man because he has money. I can't marry someone for money." (Fola)

Women, especially those without a male head of household, also came to Greece seeking economic opportunities to support their family and children. Many talked about being unable to fulfill the role of mother and provider in the absence of breadwinners. They had to migrate to provide for the children they had left behind:

"I left because of the economic crisis. This is my problem. I worked for seven years in a hospital but if you get 35 Euros a month you can't do anything with your life. And when your kids grow up what are you going to do? My husband died and my children are married. I have to do something to survive because I don't get the pension. I can't go forward with a chicken and a goat in the village.” (Mzia, Georgia)

In contrast to other accounts in refugee studies which often portray women as being swept up in forced migration journeys (Author, 2011), our participants claimed that the decisions to undertake the illicit journey were their own. They had all identified Europe as a destination themselves, and had been determined to travel there. Although many described circumstances 
where family and others had attempted to dissuade them from making the journey, pointing to another element of women's stories of migration that has been highlighted in the literature; that is women who decide to stay and encourage others to do so too (Andersson, 2014), most were, at least initially, facilitated by family members or close connections, with the preliminary arrangements made on their behalf by a member of their extended domestic group.

All were facilitated and described multiple actors who assisted them at different points in their journey. Charges were high, ranging between 6000 and 20,000 euros for the trip. All but one paid that money before embarking on their journey or in installments along the way. Only one woman reported paying after arrival in Greece. All said that their facilitators made all the detailed decisions and arrangements about exactly how and when the border would be crossed.

In terms of their knowledge of border control prior to their journey the women fell into four distinct groups. First, women from Cap Verde, Nigeria and Dominican Republic, did not know what would happen at the border, did not understand the consequences of having no or fraudulent documentation or even that they would have irregular status. Similarly, participants from Eritrea and Somalia had some idea that it would be difficult but appeared to have no specific details about what would happen upon arrival. In contrast to the relative ignorance of the first two groups, women from Iraq had a more developed understanding of the difficulties they would face, including those seeking protection, while finally, we interviewed a number of Georgian nationals who had made repeated attempts to cross, and thus were fully cognizant of what awaited them.

Understandably, those with little or no knowledge of what would happen at the border as well as women seeking protection, fleeing conflict and violence, reported that border protection 
was not a consideration in their decisions about whether, how and when to cross the border. In fact, most women found border protection almost unfathomable. They could not reconcile why and how they had come to Greece with their treatment upon arrival.

In other contexts, it has been contended that international familial and ethnic networks furnish anticipatory flight with high levels of information about exactly what will happen and when (Havinga and Bocker, 1999). In Greece, however, where there is intense border protection in a state experiencing an ongoing arrivals that strain capacity, alongside significant, popular fears of immigration and unprecedented EU resources dedicated to securing border, there nonetheless remains great uncertainty and unpredictability in terms of what actually does happen at the border. From the interview sample only those women whose country of origin was geographically proximate to Greece had a basic working knowledge of what to expect at or soon after crossing the border. As a result, they were the only ones who had considered the likely consequences in their decision-making. This group still reported being deceived by facilitators about particular details including the physical and other risks of the journey, post arrival work and their likelihood of onward mobility.

Another key finding lay in the fact that only women from Georgia referred to their facilitators in criminal terms, often calling them 'mafia'. Everyone else interviewed described chains of actors with varying relations to one another ${ }^{11}$. Different people performed distinct roles from the country of origin to arrival at the Greek border. All women talked about relying on these chains of operators (smugglers) because of the dangers of travelling unaccompanied, thus, breaking the dichotomist script of smugglers as predators and migrants and asylum seekers as victims that dominates narratives of clandestine migration (Sanchez, 2017):

\footnotetext{
11 This could be attributed to what Janet Roitman (2013) has termed as the 'ethics of illegality'; that is, a space of ethics that is construed by people on the move, in which the use of illicit modes of travel (i.e. smuggler, fake documents, etc.), otherwise criminalised by European authorities, is normalised.
} 
The boat took us to a Greek village. And we were 6 Georgians. And we had another 2 guys who took us here. It can't be that six women can travel by themselves. Someone has to be with...the other two were the people who do this business. (Irema)

At first, most of the women reported that they had considered border police to be part of their rescue following dangerous river and land crossings. As such, they even sought out the police to bring to an end their journey and the physical risks and pains they were enduring. They did not view border police, in other words, as part of a coercive regime designed to repel their journey or disrupt and deter the chains of facilitators that got them to the border. Instead, they considered them to be people who would bring their physical risks to an end. This finding mirrors other work, which has found humanitarianism and policing to be linked with the management of populations considered at risk (Pallister-Wilkins, 2015; Aas and Gundhus, 2015).

Indeed, the women enumerated multiple physical risks they had experienced in making the journey and in crossing the border. Such risks included sexual violence en route and the measures taken by smugglers to conceal their entry. It also encompassed crossing the Evros River and overcoming Greece's border fortifications. Their experiences resonated with the words of Banerjee as "bodies [pitted] against the border and the superstructure of state security" (2010: xvi). As Liyana, who had traveled from the Dominican Republic, described matters:

I wanted to come to Greece because some persons had come here, some friends and they didn't tell me that it would be dangerous to come here. When you come here, they don't tell you that you are going to pass through the mountains, that it's going to be dangerous for your life, that you have to cross a river... When we got to the river, they put us on a boat and they left and they said that when you 
arrive on Greek soil you have to walk. In the river I lost everything, I was without clothes. And then they arrested me in Orestiada. (Liyana)

Women like Liyana weighed up the risks of remaining in their countries of origin with those associated with irregular migration. They repeatedly reported a willingness, or perhaps more accurately an expectation and capacity, to suffer in their bid to forge a new life.

Chiora: ...they told me I was going to hide in a bus for two hours

Interviewer: In the bus? Where, in the luggage compartment?

Chiora: Not there. They had somewhere else. Under the chairs and above the wheels like (pause) what is that (pause) like a coffin. And in reality I was there for 24 hours.

It was only once women succeeded in their clandestine entry that their views of the police began to change. Few women understood the legal arrangements governing their stay in Greece. Only some had previously heard of the white paper ${ }^{12}$ notice for 30 days that is distributed at the border. It was with some surprise then, that they discovered that the Greek police were not figures of rescue, but rather personnel who would deport them. As such they could not be called upon for assistance, even by those women who had experienced criminal victimisation $^{13}$

Together, our interviews suggested that while the border and its control profoundly impact women's journeys it does not significantly figure in their migration decision-making. The border, or its control, is not their main focus. This view, as we will show below, contrasts significantly with that of the police. In the following section we turn to examine their accounts.

\footnotetext{
${ }^{12}$ The white paper is an administrative notice written only in Greek which gives them 30 days to file for asylum or leave the country (HRW, 2008).

${ }^{13}$ For a similar observation on the practices of border police see Williams' work (2015), which examines the role care plays as a technology for border enforcement in the US only to secure migrants' effective deportation.
} 


\section{Race, gender and border control}

Unlike the nuanced accounts the women provided about their motivations for crossing borders and the ways they journeyed, the border police overwhelmingly depicted irregular migrants and their decision-making in terms of the women's race and gender. The detainees, in their view, were inadequate women and representatives of failing cultures. The dynamics of border control and irregular migration was conveniently washed aside in their testimonies by energetic and dogmatic claims about the women's criminal, sexually deviant and subhuman nature.

For some officers, the women had simply been exploited ${ }^{14}$.

"They get fooled. Before they arrive here they are told that they are going to work in houses and such and they end up on the street. They don't know what they are doing and where they are going. Women don't have an idea" (Ivan)

The criminality of women, in this view, sprang from their inherent naivety. Like children, they merely did what men told them to do. The best way of managing them, one officer made clear, was, therefore to be firm. 'When they resist, I shout at them and they stop,' Jacinta asserted.

Although this same officer claimed that 'women are more innocent' than men, most of her colleagues perceived their charges in more negative terms as deviants and sub-humans. Like Lombroso's 'criminal women', female detainees were perceived through a racialized prism as morally and intellectually distinct from and lesser than Greek citizens. Their views provided further evidence of the racialization and sexualisation of migrant women that has been noted by researchers in a range of contexts (for example, Jiwani, 2005, Kapur, 2005,

\footnotetext{
${ }^{14}$ Similarly, Pallister-Wilkins (2015) argues that the policing of groups who are both at risk and a risk (Aradau, 2004), who are in need of both care and control, is a constant feature of the border police's daily work in Greece.
} 
Brennan, 2004, Angel-Ajani, 2003b; Scambler, 2007). Both work to culturally assign and explain women's migration as primarily deviant. In this narrative race and gender work to deligitimise women as transnational migrants, especially in the face of increasing border control. Often cast in nationalist terms, this view of the detainees obscured the global inequalities, regional conflict or trauma that the women emphasized in their accounts of migration.

Interviews for this research were conducted at a time when the Greek state was in crisis and had broadly accepted it was unable to effectively provide for sizeable groups of its own citizens. Under such conditions of austerity, the provision of shelter to undocumented migrants was considered by the border police as a marker of a civilised state in which Greeks (us) were pitted against uncivilised masses (them).

“They are not able to freely move around, they can't talk to anyone, they just come to Greece and become slaves. So in a way in here they have a better life, because we feed them and provide them with accommodation." (Fieldnotes, December 2011; Detention Centre Officer)

In this binary, women were marked out by traditional gender categories, difficult to manage because of their biological needs, not to be trusted because of their nature.

One the one hand, Ivan, noted,

"I don't think there are any differences with men; only as far as the female nature is concerned. For example the other day we didn't' have enough money to buy sanitary towels so some women had a problem. We get by though.

On the other, his colleague Xenia warned, 
"they are sly, not as women from these countries, as women in gender. But we are sly too. In general all women are sly so you have to treat them like this...Women used their female nature to get what they wanted from men. She is not going to do the same to me. I am a woman and I am sly too. We have the same slyness as a sex. I know how they are thinking and I can act accordingly. Of course the same applies when I am dealing with transvestites." (Xenia)

Above all, staff spoke of female detainees as exemplars of failed or unacceptable cultures (Volpp, 2000). In terminology reminiscent of the French colonists depicted by Frantz Fanon in Wretched of the Earth, the officers viewed (certain) detainees as little more than animals. Outspoken Xenia tried to explain. "Iraqis have a certain mentality," she began,

"that women have to be animals. I'm not saying this to offend them but this is their way of thinking because of their religion, their culture, as a country, as a people. Women have to animals, be uneducated, not knowing what's going on around them, have babies all the time...I mean women are reproduction machines and nothing else. And I can't say they are very loving towards their kids because these women have learned that from the age of 13, 14 -when they get sold, because marriage there is a transaction- that you have children and nothing else, that your husband treats you inhumanely and that he has another 15 women who he treats the same way. If you watch them carefully, because I do in order to assess their behaviour towards the baby. They are very cold and it's not their fault they are like this, it's their upbringing. If you have heard what they do to girls' genitals in these countries... I believe that this is what makes them act inadequately. (Xenia) 
Such anthroporacialism, justified through culturalist narratives, had deeply corrosive effects and justified the women's maltreatment; animals do not deserve to be treated as humans. It also hived off sections of the population from others, creating a hierarchy of deserts and culpability.

The racialized nature of such matters was particularly evident in the narratives of criminality many officers attributed to some of the women in their care. While the women did not talk about their intention to work in the sex industry, or of transactional sex, ${ }^{15}$ officers routinely demonized and ridiculed them on this basis and evidently perceived them as criminals due to their assumed or actual involvement in sex work. Sex work was always associated with deviance despite sex work being legal and regulated in Greece. As Angel-Anjani described many years ago in Italy, this perception was intimately bound up with racialization of immigrant women and a reliance on cultural stereotypes (Angel-Ajani, 2003b). Nigerian women were particular targets.

"Nigerians create more problems... They are into voodoo and stuff and you can't communicate with them. Moreover they have a different mentality, a street mentality. They come here and become prostitutes and they become harder than other women. Basically they are men.” (Ivan)

A perceived willingness to engage in sex work was seen as fitting with the cultural othering of women from some countries. Being seen as a sexual agent was evidence of a bad culture. Yet, for other border police, sex work, and its normalisation by some women in their charge, was seen as evidence of their inherent deviance that not only disrupted acceptable gendered performance but distorted broader (Greek) gender relations.

\footnotetext{
15 Transactional sex refers to the exchange of sex for material support, usually in the form of a relationship.
} 
"You see other women, for example, Russian or Ukrainian, mainly from the eastern block, that come here and they know that they come here for prostitution; they are not opposed to it. There are many women who support their decision very much. No matter how weird we think it is. I mean when I said to one girl that 'you are 18 years old, how can you let all these men use your body?', her answer was 'this is my job, like yours is to be a police officer. I am serving people'. Here we consider it as humiliation. They openly say that they don't do any harm; 'like you are a policewoman, I am a prostitute. Who is going to do this job?' They don't think of it as being awful, they think it's normal. And this is how they get their men.” (Xenia)

As the officers' testimonies made clear, women who irregularly cross borders are doubly stigmatized, first for their contravention of gender-based expectations and second, for their breach of the border. This pattern broadly confirms decades of feminist criminological research on women's offending as being seen as 'doubly bad' especially for women of colour (Carlen, 2013; Chesney-Lind, 1999, 2006; Chesney-Lind \& Eliason, 2006). Ironically, women's efforts to meet changing gender expectations in their countries of origin of familial obligation, especially regarding financially providing for their families, does not factor into such assessments. There is no attempt to recuperate narratives of good motherhood to explain what drives some women to seek out financial security through insecure migration and illicit labour. Women's own narratives of providing for their children and aging parents were unable to disrupt scripts of failed gender and culture at the border.

As Brennan (2004) has cogently argued, even though migrant women have freed themselves of the constraints of traditional gender ideologies in home communities, once they migrate they often face a new set of gendered expectations. These expectations profoundly shape their interaction with border control. "We respect women because they are women," Dimitris 
asserted. "Women come in usually with big groups with their kids and husbands. Young girls go straight on the streets. They make them prostitutes. Even though women just want to be with their families. They don't have a choice. Once they leave their country the biggest torture begins." (Dimitris)

\section{CONCLUSION}

This research sought to bridge the gap that Liisa Malkii (1997) identified between the ways women migrants are seen by others and how they view themselves. We are considering this gap at a critical time in the European project of border control during a time of heightened awareness of trafficking, particularly into the sex industry. These concerns dominate debates around women's irregular mobility into Europe and have resulted in the construction of irregularly mobile women as victim or potential victim, often with a concomitant loss of agency and voice.

The extant literature indicates the ways women's bodies are considered racially and sexually dangerous as they approach national borders - primarily to themselves but also to nation states and are hence increasingly rejected or immobilised (see, inter alia, Brennan, 2004; Kapur, 2005; Lee, 2007, Scambler, 2007; Vanwesenbeeck, 2012). In short, women of particular ages and races, travelling in specific configurations often have a reverse burden of proof to show they are not, or will not be, a victim of trafficking (Pickering and Ham, 2013). However, our research in Greece suggests the sexualisation and racialization of women extends well beyond these prevailing European concerns. 
Border control not only refers to the power to reject irregular border crossing, technologically, legally or physically. It also captures the capacity to reject on moral grounds those who have crossed borders (Pallister-Wilkins, 2015). In this task, ideas of race and gender offer crucial resources for the regulation of mobility. In the case of women crossing the Greece-Turkey border, border police justified their actions and the harsh institutions in which they worked by appealing to cultural stereotypes and norms. In turn, such beliefs allowed them to turn away from those in their care and overlook their suffering.

Traditional gendered and racial ideologies uphold and legitimate the spaces created by the hyper-politics of border control. Gender roles operated as a drag on women's international migration, even when it was irregular, delegitimizing them as transnational migrants. The sorting of desirable from undesirable migrants at the border is heavily invested in 'civilising' tropes that are little more than racialised and gendered moralities. Border control has provided another, potent opportunity not only to reject, but to demean and diminish racially othered women. The complexity of women's survival and their labour fade in the spaces of border control. Yet there are few indications that women's irregular border crossing will change as a result. For women, these spaces are not the focus of their survival. Yet, officials keep their individual and collective racial and gendered stare fixed upon the woman and the border. This incongruence is surely unsustainable.

\section{References}

Aas, K. F., 2005. Getting ahead of the game: Border technologies and the changing space of governance. Global Surveillance and Policing. Borders, Security, Identity. Portland, OR: Willan Publishing.

Aas, K., 2011. 'Crimmigrant' bodies and bona fide travellers: Surveillance, citizenship and global government. Theoretical criminology. 15 (3), $331-346$.

Aas, K and Bosworth, M. (Eds.), 2013.The Borders of Punishment: Migration, Citizenship and Social Exclusion. Oxford: Oxford University Press. 
Aas, K., and Gundhus, H. 2015. 'Policing Humanitarian Borderlands: Frontex, Human Rights and the Precariousness of Life', British Journal of Criminology, 55(1): 1-18.

Amnesty International, 2010. Greece: Irregular migrants and asylum-seeker routinely detained in substandard conditions. London: Amnesty International

Amnesty International, 2013. Frontier Europe: Human Right's Abuses on Greece's border with Turkey. London: Amnesty International Publication

Andersson, R. (2014). Illegality, Inc.: Clandestine migration and the business of bordering Europe. Oakland: University of California Press.

Andreas, P., 2003. Redrawing the line: borders and security in the twenty-first century. International security, 28 (2), 78-111.

Angel-Ajani, A., 2003.The Racial Economies of Criminalization, Immigration, And Policing in Italy. Social justice, 30 (3), 48-62.

Angel-Anjani, A., 2003bA Question of Dangerous Races? Punishment \& Society 2003 5: 433.

Author, M., 2008.

Bigo, D. and Elspeth G., Eds. (2005) Controlling Frontiers: Free Movement Into and Within Europe. Aldershot: Ashgate.

Bosworth, M. and Guild, M., 2008. Governing through migration control: Security and Citizenship in Britain.The British journal of criminology, 48 (6), 703 - 719.

Brennan, D., 2004. Women work, men sponge, and everyone gossips: Macho men and stigmatized/ing women in a sex tourist town. Anthropological quarterly, 77 (4), 705-733.

Carpenter, J., 2006. The gender of control. In: Weber, L. and Pickering, S. Borders, mobility and technologies of control. Netherlands: Springer, 167-177.

Carlen, P. (Ed.)., 2013. Women Punishment. Devon: Willan.

Chesney-Lind, M., and Hagedorn, J. (Eds.), 1999. Female gangs in America: Essays on girls, gangs and gender. Chicago, IL: Lake View Press.

Chesney-Lind, M., 2006.Patriarchy, crime, and justice feminist criminology in an era of backlash.Feminist criminology, 1 (1), 6-26.

Chesney-Lind, M., and Eliason, M., 2006. From invisible to incorrigible: The demonization of marginalized women and girls. Crime, media, culture, 2 (1), 29-47.

Crawley, H., 1999. Women and Refugee Status: Beyond the Public/Private Dichotomy in UK Asylum Policy. In D. Indra (ed.), Engendering Forced Migration: Theory and Practice. New York: Berghahn, 308-333. 
European Committee for the Prevention of Torture and Trauma, 2011. Public Statement Concerning Greece, http://www.cpt.coe.int/documents/grc/2011-10-inf-eng.htm

Fanon, F. 1963, The Wretched of the Earth, Farrington, C. (trans.), Grove Press, New York, USA

Fassin, D., 2011. Policing Borders, Producing Boundaries. The Governmentality of Immigration in Dark Times.Annual review of anthropology, 40 (2011), 213 - 226.

FRA (European Union Agency for Fundamental Rights), 2011.Coping with a fundamental rights emergency: The situation of persons crossing the Greek land border in an irregular manner. Austria: FRA.

Frontex. (2011a). General Report 2011. Warsaw: Frontex.

Frontex. (2011b). RABIT Operation 2010 Evaluation Report.Warsa: Frontex.

Gerard, A. (2014). The Securitization of Migration and Refugee Women. Abingdon: Routledge.

Gerard, A and Pickering, S., 2012. The Crime and Punishment of Somali women's extra-legal arrival in Malta.British journal of criminology, 52 (3), 514-533.

Goldsmith, A., \&Sheptycki, J., 2007. Crafting Transnational Policing; State-Building and Global Policing Reform. London: Hart.

Green, P., \&Grewcock, M., 2002. The war against illegal immigration: State crime and the construction of a European identity. Current issues criminal justice, 14 (2002), 87.

Grewcock, M., 2011. Punishment, deportation and parole: The detention and removal of former prisoners under section 501 Migration Act 1958. Australian and New Zealand journal of criminology, 44 (1), 56- 73.

Havinga, T., \& Böcker, A., 1999. Country of asylum by choice or by chance: Asylum-seekers in Belgium, the Netherlands and the UK. Journal of ethnic and migration studies, 25(1), 4361.

Human Rights Watch, Stuck in a Revolving Door: Iraqis and Other Asylum Seekers and Migrants at the Greece/Turkey Entrance to the European Union. New York: Human Rights Watch, 2008.

Human Rights Watch (2013) Unwelcome guests. Greek police abuses of migrant in Athens. USA: Human Rights Watch.

Jiwani, J., 2005. Walking a tightrope: The many faces of violence in the lives of racialised immigrant girls and young women. Violence against women, 11(7), 846-875.

Kapur, R., 2005. Cross-border movements and the law: renegotiating the boundaries of difference. Trafficking and Prostitution Reconsidered. London: Paradigm. 
Lee, M. (Ed.), 2007.Human trafficking. Loftus: Routledge.

Maher, J.M., Pickering, S.J., and Gerard, A.F., 2013. Sex Work: Labour, Mobility and Sexual Services. Abingdon: Routledge

Malkki, L. H., 1997. News and culture: Transitory phenomena and the fieldwork tradition. In Gupta, A., \& Ferguson, J. (Eds.). Anthropological locations: Boundaries and grounds of a field science. California: University of California Press., 86-101.

Piper, N., 2003.Wife or worker? Worker or wife? Marriage and crossborder migration in contemporary Japan. International journal of population geography, 9 (6), 457-469.

Melossi, D., 2003. In a Peaceful Life: Migration and the Crime of Modernity in Europe/Italy. Punishment and society, 5 (4), 371-97.

Morrison, A. R., Schiff, M. W., and Sjöblom, M. (Eds.), 2007.The international migration of women. Washington, DC: World Bank Publications.

Pallister-Wilkins, Polly. (2015) The Humanitarian Politics of European Border Policing: Frontex and Border Police in Evros. International Political Sociology, doi: 10.1111/ips. 12076

Pickering, S., and Ham, J., 2013, Hot Pants at the Border: Sorting Sex Work from Trafficking, British Journal of Criminology.

Pickering, S., \& Weber, L., 2006. Borders, mobility and technologies of control. Netherlands: Springer

Pickering, S., \& Weber, L., 2013. Policing Transversal Borders. In Aas, K and Bosworth, M. (Eds.). The Borders of Punishment: Migration, Citizenship and Social Exclusion. Oxford: Oxford University Press, 93-110.

Richter, S. M., Taylor, J. E., and Yúnez-Naude, A., 200. Impacts of policy reforms on labor migration from rural Mexico to the United States. In Borjas, G. J. (Ed.).Mexican immigration to the United States.Chicago: University of Chicago Press, 269-288.

Salter, M. B., 2007. Governmentalities of an airport: heterotopia and confession. International political sociology, 1 (1), 49-66.

Sanchez, G. 2017. 'Critical Perspectives on Clandestine Migration Facilitation: An Overview of Migrant Smuggling Research', Journal on Migration and Human Security, Volume 5 Number 1: 9-27.

Sanchez, G. 2016. Human Smuggling and Border Crossing. Abingdon: Routledge.

Sassen, S., 1999. Cracked casings: Notes towards an analytics for studying transnational processes. In Abu-Lughod, J. L. (Ed.). Sociology for the twenty-first century: Continuities and cutting edges, 134-145. 
Scrambler, G., 2007. Sex work stigma: Opportunistic migrants in London. Sociology, 41 (6), 1079-1096.

Triandafyllidou, A. and Veikou, M., 2002. The hierarchy of Greekness: Ethnic and national identity considerations in Greek immigration policy. Ethnicities, 2 (2), 189-208.

Triantafyllidou, A. and Ambrosini, M. 2011. 'Irregular Imimmigration Control in Italy and Greece: Strong Fencing and Weak Gate-keeping serving the Labour Market'. European Journal of Immigration and Law 13: 251-273.

Tsianos, V. and Karayakali, S. 2010 Transnational Migration and the Emergence of the European Border Regime: An Ethnographic Analysis. European Journal of Social Theory, 13: 3, 373-387.

Vanwesenbeeck, I., 2001. Another Decade of Social Scientific Work on Sex Work: A Review of Research 1990-2000. Annual review of sex research, 12 (1), 242-289.

Vaughan-Williams, N. 2012. Border Politics: The Limits of Sovereign Power. Edinburgh: University of Edinburgh Press.

Volpp, L., 2000. 'Blaming Culture for Bad Behaviour,' Yale Journal of Law and the Humanities, 12: 89 - 116.

Weber, L., 2013. The Policing of Non-Citizens. London: Routledge.

Weber, L., 2006. The shifting frontiers of migration control. In Pickering, S., \& Weber, L. Borders, mobility and technologies of control. Netherlands: Springer, 21-43.

Weber, L., \& Bowling, B., 2008. Valiant beggars and global vagabonds: Select, eject, immobilize. Theoretical criminology, 12 (3), 355-375.

Weber, L. and Pickering, S., 2011. Globalisation and Borders: Death at the Global Frontier. London: Palgrave Macmillan.

Wilson, D., \& Weber, L. (2002). Surveillance, risk and preemption on the Australian border. Surveillance \& Society, 5 (2).

Williams, J.M. (2015) From humanitarian exceptionalism to contingent care: Care and enforcement at the humanitarian border. Political Geography 47: 11-20.

Wonders, N. A., 2007. Globalization, border reconstruction projects, and transnational crime. Social justice, 34 (2), 33-46.

Author 2004

Author 2005

Author 2006

Author 2011 
Author 2013

Author 2014 